\title{
Developmental patterns of enzymes in mouse testis
}

\author{
R.-S. Shen* and I. P. Lee \\ National Institute of Environmental Health Sciences, \\ National Institutes of Health, \\ Research Triangle Park, North Carolina 27709, U.S.A.
}

\begin{abstract}
Summary. Study of the activities of hyaluronidase, lactate dehydrogenase isoenzyme-X and the dehydrogenases of sorbitol, $\alpha$-glycerophosphate, glucose- 6 -phosphate, malate, glyceraldehyde-3-phosphate and isocitrate in the testes of mice of different ages showed that the changes were correlated with the stages of spermatogenic cell differentiation. The first 4 enzymes had activities which were low in newborn mice and high in adults; this pattern was reversed for the other enzymes.
\end{abstract}

\section{Introduction}

Studies of testicular enzymes have two main purposes: first, to determine enzyme activities in different cell types to understand biochemical changes during germ cell differentiation, and second, to use testicular enzymes as biochemical markers for elucidating control and regulatory mechanisms of spermatogenesis. The enzymes in rodent testes at different stages of development have been studied histochemically and biochemically. Hyaluronidase (E.C.3.2.1.35), sorbitol dehydrogenase (E.C.1.1.1.14), lactate dehydrogenase (isoenzyme-X) (E.C.1.1.1.27), hexokinase (sperm type) (E.C.2.7.1.1), cyclic nucleotide phosphodiesterase (E.C.3.1.4.17), 5'-nucleotidase (E.C.3.1.3.5), S-adenosyl-L-methionine decarboxylase (E.C.4.1.1.50) (see Gomes \& VanDemark, 1974, for review), carnitine acetyltransferase (E.C.2.3.1.7) (Schanbacher, Gomes \& VanDemark, 1974), and $\alpha$-glycerophosphate dehydrogenase (E.C.1.1.1.8) (Schenkman, Richert \& Westerfeld, 1965) first appear in spermatocytes or spermatids and then increase rapidly to reach maximum levels in spermatozoa when spermatogenesis is complete. The activities of $\gamma$-glutamyl transpeptidase (E.C.2.3.2.2.) (Hodgen \& Sherins, 1973), $\beta$-glucuronidase (E.C.3.2.1.31), uridine diphosphatase (E.C.3.6.1.6), acid phosphatase (E.C.3.1.3.2) isoenzymes I and II, ornithine decarboxylase (E.C.4.1.1.17), glucose-6-phosphate dehydrogenase (E.C.1.1.1.49) (see Gomes \& VanDemark, 1974, for review), and malate dehydrogenase (E.C.1.1.1.37) (Ambadkar \& George, 1964) are highest in Sertoli cells, interstitial cells, or spermatogonia and then decrease gradually as spermatocytes, spermatids and spermatozoa appear sequentially in the seminiferous epithelium.

In the present study, 8 enzymes were selected for quantitative determination of their activities during spermatogenic development in mice. They were hyaluronidase, sorbitol dehydrogenase, lactate dehydrogenase (isoenzyme-X), $\alpha$-glycerophosphate dehydrogenase, malate dehydrogenase, glucose-6-phosphate dehydrogenase, isocitrate dehydrogenase (E.C.1.1.1.42) and glyceraldehyde-3phosphate dehydrogenase (E.C.1.2.1.12).

\section{Materials and Methods}

Animals. Male CD-1 mice, 1-120 days of age, were used. After weaning, animals were housed five per cage with food and water freely available. The mice of three groups, each consisting of between

* Present address: Division of Biochemistry, Department of Human Biological Chemistry and Genetics, The University of Texas Medical Branch, Galveston, Texas 77550, U.S.A. 
35 neonatal and 3 adult mice as the mice grew, were killed by decapitation or cervical dislocation. The testes were promptly removed, chilled on ice and weighed together. After taking samples for histological study, testes were homogenized $(1: 9 \mathrm{w} / \mathrm{v})$ in ice-cold $10^{-3} \mathrm{M}$-tris buffer, $\mathrm{pH} 7 \cdot 0$, containing $0.1 \%$ cetyltrimethylammonium bromide. The crude homogenate was centrifuged at $9000 \mathrm{~g}$ for 30 min at $4^{\circ} \mathrm{C}$, and the supernatant filtered through a Millipore filter $(0.45 \mu \mathrm{m})$. This solution was used for enzyme assays. The epididymis and vas deferens were also removed from mice $\geqslant 20$ days of age for enzyme studies.

Enzyme assays. All assays were performed in 3 groups and each group in triplicate at $32^{\circ} \mathrm{C}$. The reagents used are shown in Table 1. Hyaluronidase was assayed by the method of Males \& Turkington (1970) and lactate dehydrogenase (isoenzyme-X) by the method of Goldberg \& Hawtrey (1967) using $\alpha$-ketovalerate as substrate. The activities of sorbitol dehydrogenase, $\alpha$-glycerophosphate dehydrogenase, glyceraldehyde-3-phosphate dehydrogenase, isocitrate dehydrogenase, glucose-6phosphate dehydrogenase and malate dehydrogenase were determined by the methods published elsewhere (Bergmeyer, 1974). Enzyme activities were expressed as $\mu \mathrm{mol}$ of product formed $/ \mathrm{hr} / \mathrm{mg}$ protein.

Table 1. Final concentrations of reagents used in 3-ml reaction mixtures to assay testicular enzymes of mice

\begin{tabular}{|c|c|c|c|c|}
\hline Enzyme & Substrate & Coenzyme & Buffer & Other \\
\hline $\begin{array}{l}\text { Sorbitol } \\
\text { dehydrogenase }\end{array}$ & $66.6 \mathrm{~mm}-\beta$-D-Fructose & $0.09 \mathrm{~mm}-\mathrm{NADH}$ & $\begin{array}{l}66.6 \text { mM-Tris, } \\
\text { pH } 7.5\end{array}$ & \\
\hline $\begin{array}{l}\text { Glyceraldehyde-3- } \\
\text { phosphate } \\
\text { dehydrogenase }\end{array}$ & $\begin{array}{l}0.5 \mathrm{~mm} \text {-DL-Glyceralde- } \\
\text { hyde-3-phosphate }\end{array}$ & $0.23 \mathrm{~mm}-\mathrm{NAD}$ & $\begin{array}{l}13.0 \text { mm-Sodium } \\
\text { pyrophos- } \\
\text { phate, } \mathrm{pH} 8.5\end{array}$ & $\begin{array}{l}26.0 \mathrm{~mm} \text {-Sodium arsenate, } \\
3.33 \mathrm{~mm} \text {-Dithioerythritol }\end{array}$ \\
\hline $\begin{array}{l}\alpha \text {-Glycerophosphate } \\
\text { dehydrogenase }\end{array}$ & $\begin{array}{l}0.78 \mathrm{~mm} \text {-Dihydroxy } \\
\text { acetone phosphate }\end{array}$ & $0.22 \mathrm{~mm}-\mathrm{NADH}$ & $\begin{array}{l}27.5 \text { mm-Tri- } \\
\text { ethanolamine, } \\
\text { pH } 7.6\end{array}$ & \\
\hline $\begin{array}{l}\text { Glucose-6- } \\
\text { phosphate } \\
\text { dehydrogenase }\end{array}$ & $\begin{array}{l}3 \cdot 33 \text { mM-Glucose-6- } \\
\text { phosphate }\end{array}$ & $0.19 \mathrm{~mm}-\mathrm{NADP}$ & $\begin{array}{l}49 \cdot 5 \text { mm-Tris } \\
\text { pH } 7 \cdot 8\end{array}$ & $2.97 \mathrm{~mm}^{-\mathrm{Mg}^{++}}$ \\
\hline $\begin{array}{l}\text { Lactate } \\
\text { dehydrogenase } \\
\text { (isoenzyme-X) }\end{array}$ & $\begin{array}{l}0.13 \mathrm{~mm}-\alpha-K e t o v a l e r i c \\
\text { acid }\end{array}$ & $0.06 \mathrm{mM}-\mathrm{NADH}$ & $\begin{array}{l}27 \cdot 5 \text { mm-Sodium } \\
\text { phosphate, } \\
\text { pH } 7 \cdot 4\end{array}$ & \\
\hline $\begin{array}{l}\text { Isocitrate } \\
\text { dehydrogenase }\end{array}$ & $0.5 \mathrm{~mm}$-DL-Isocitrate & $0.13 \mathrm{mM}-\mathrm{NADP}$ & $\begin{array}{l}0.28 \text { mM-Tris, } \\
\text { pH } 7.5\end{array}$ & $3.33 \mathrm{~mm}^{-\mathrm{Mn}^{++}}$ \\
\hline $\begin{array}{l}\text { Malate } \\
\text { dehydrogenase }\end{array}$ & $\begin{array}{l}0.25 \mathrm{mM} \text {-cis-Oxaloacetic } \\
\text { acid }\end{array}$ & $0.09 \mathrm{~mm}-\mathrm{NADH}$ & $\begin{array}{l}91.7 \text { mm-Sodium } \\
\text { phosphate } \\
\text { pH } 7.5\end{array}$ & \\
\hline Hyaluronidase & $0.6 \mathrm{mg}$ Hyaluronic acid* & & $\begin{array}{l}5 \cdot 0 \text { mM-Sodium } \\
\text { phosphate- } \\
\text { citrate, } \mathrm{pH} 4 \cdot 5\end{array}$ & $\begin{array}{l}53.6 \mathrm{~mm}-p \text {-Dimethylamino- } \\
\text { benzaldehyde, } 20.0 \mathrm{~mm} \\
\text { sodium borate }\end{array}$ \\
\hline
\end{tabular}

*Final volume $4 \mathrm{ml}$.

Protein determinations. The total protein concentration of each supernatant was determined by the method of Lowry, Rosebrough, Farr \& Randall (1951).

Histology. Testicular tissue samples were fixed in Bouin's fluid for $24 \mathrm{hr}$, embedded in paraffin wax, and sections cut at $5 \mu \mathrm{m}$ were stained with haematoxylin and eosin.

\section{Results}

Testis weight. Testicular weights increased slowly from 1 to 15 days of age. Maximum growth rates occurred between 20 and 40 days of age followed by a slower rate of growth until 120 days of age.

Changes in the activities of enzyme during development of the testis. The developmental patterns of these enzymes are shown in Text-fig. 1. Activities of hyaluronidase and lactate dehydrogenase 


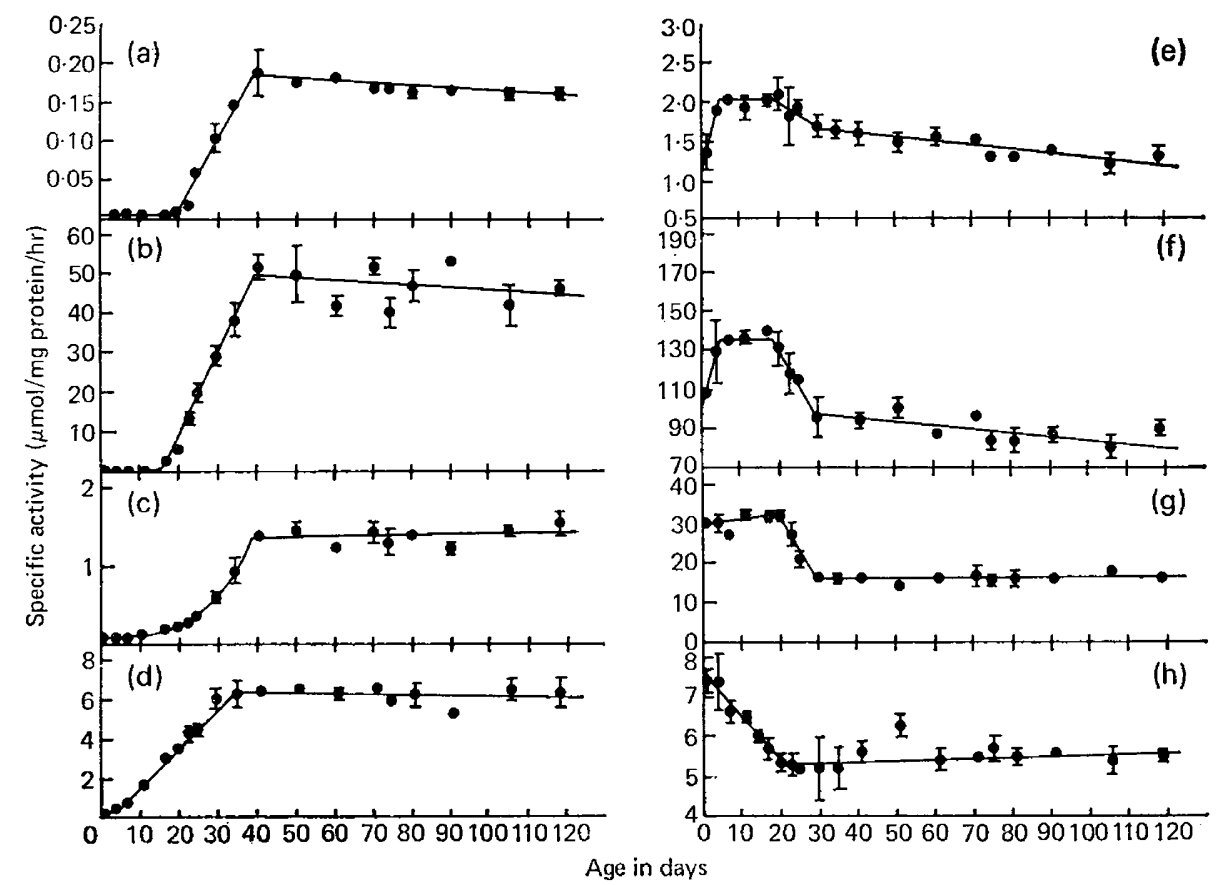

Text-fig. 1. The developmental patterns of enzymes in the testes of mice of different ages. (a) Hyaluronidase; (b) lactate dehydrogenase isoenzyme-X; (c) sorbitol dehydrogenase; (d) $\alpha$-glycerophosphate dehydrogenase; (e) glucose-6-phosphate dehydrogenase; (f) malate dehydrogenase; (g) glyceraldehyde-3-phosphate dehydrogenase; $(\mathrm{h})$ isocitrate dehydrogenase. Results are expressed as means \pm S.D. of three determinations. Points without bars indicate S.D. less than 0.05 (a), 0.50 (b), 0.06 (c), 0.20 (d), 0.03 (e), $2 \cdot 11$ (f), 1.23 (g) and $0.12(\mathrm{~h})$.

isoenzyme-X were almost undetectable until 20 and 17 days of age, respectively, but they then rose markedly and remained unchanged between 40 and 120 days of age. Levels of sorbitol dehydrogenase and $\alpha$-glycerophosphate dehydrogenase were detectable at 1 day of age; they increased rapidly until 40 and 35 days of age, respectively, and then remained at constant levels. The activities of glucose-6phosphate, malate, glyceraldehyde-3-phosphate and isocitrate dehydrogenases were high at birth but had declined by 30 days of age. During adulthood, the levels of glucose-6-phosphate and malate dehydrogenases tended to decline, but those of glyceraldehyde-3-phosphate and isocitrate dehydrogenase remained unchanged.

Sorbitol dehydrogenase and glucose-6-phosphate dehydrogenase activities in testis, epididymis and vas deferens. These are shown in Text-figs 2(a) and 2(b). At the time when mature spermatozoa began to pass into the epididymis, the activity of sorbitol dehydrogenase had increased dramatically to a maximal value at 49 days of age, about 8 days after testicular activity had reached adult levels. This period coincides with that required for the spermatozoa to pass from the seminiferous tubules into the epididymis. Similarly, activity in the vas deferens was not detectable until 41 days of age and maximal values were reached only by 56 days of age, i.e. a 7-day lag associated with the passage of the first wave of spermatozoa through the vas deferens. The specific activities of sorbitol dehydrogenase in testis, epididymis and vas deferens in adult animals were $1 \cdot 17,3.92$ and $0.87 \mu \mathrm{mol} / \mathrm{mg}$ protein $/ \mathrm{hr}$, respectively. The developmental patterns of glucose-6-phosphate dehydrogenase in the epididymis and vas deferens before 20 days of age are not shown because of the difficulty of obtaining enough tissue for enzyme assays. After 20 days of age, epididymal activity existed in two phases, with the transition point at about 38 days. The activity of this enzyme in the vas deferens was low and unchanged from 20 to 81 days of age. Specific activities of glucose-6-phosphate dehydrogenase in testis, epididymis and vas deferens were $1.89,2.95$ and $0.12 \mu \mathrm{mol} / \mathrm{mg}$ protein $/ \mathrm{hr}$, respectively, at 23 days of age, and 1.58 , 0.75 and $0.12 \mu \mathrm{mol} / \mathrm{mg}$ protein $/ \mathrm{hr}$, respectively, at 40 days of age. 


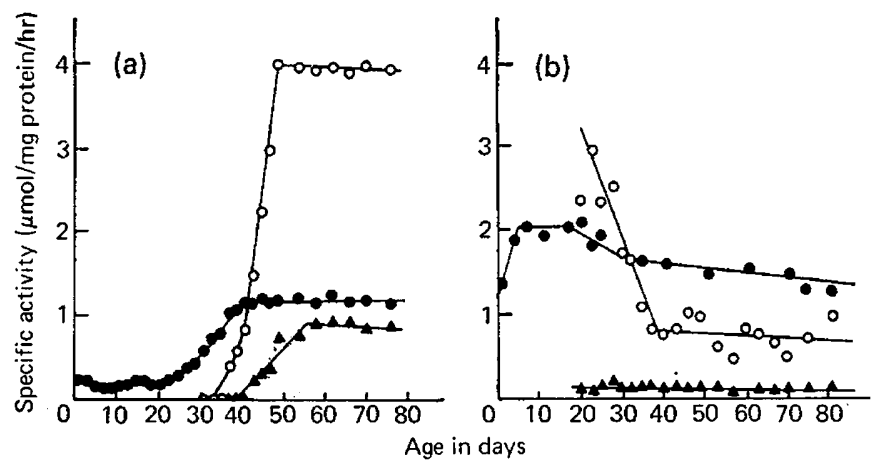

Text-fig. 2. The activity of (a) sorbitol dehydrogenase and (b) glucose-6-phosphate dehydrogenase in the testis $(\bullet)$, epididymis $(O)$ and vas deferens $(\Delta)$ of mice of different ages. Each point is the mean of three determinations.

Histological differentiation of germ cell maturation. From 1 to 9 days of age there was little spermatogenic activity in the germinal epithelium, while at 13 days of age, there was an increase in tubule size and in the number of cells per tubule, probably due to an increase in the number of early primary spermatocytes. There was a progressive increase in tubule diameter from Days 17 to 60 and a concomitant increase in the cellular content of the germinal epithelium. Late primary spermatocytes were present at 17 and 21 days of age. Spermatids progressed from the cap phase at 27 days to the acrosome phase at 32 days of age, and spermatogenesis was complete by 42 days.

\section{Discussion}

Studies of testicular enzymes have been limited by the heterogeneity of spermatogenic cells in seminiferous tubules. Although efforts have been directed toward separation of the different spermatogenic cell populations (Lam, Furrer \& Bruce, 1970; Go, Vernon \& Fritz, 1971; Lee \& Dixon, 1972; Meistrich, 1972), enzyme profiles of the specific cell types have not yet been established. Selection of testes at different stages of development before full spermatogenesis is achieved therefore offers an alternative for the study of testicular enzymes associated with spermatogenic cell types.

Two enzyme developmental patterns were distinguished in mouse testes during cellular differentiation. The activities of hyaluronidase, lactate dehydrogenase (isoenzyme-X), sorbitol dehydrogenase and $\alpha$-glycerophosphate dehydrogenase changed from low to high levels, while those of glucose-6phosphate, malate, glyceraldehyde-3-phosphate and isocitrate dehydrogenases changed from high to low levels as spermatogenesis proceeded. The two enzyme patterns crossed at puberty.

Activity of lactate dehydrogenase (isoenzyme-X) is first detectable at 17 days after birth. Since primary spermatocytes first appear at 15 days of age, the activities of this enzyme seem to be associated with spermatocytes. This conclusion is in agreement with that of Goldberg \& Hawtrey (1967). Blackshaw \& Elkington (1970) suggested that lactate dehydrogenase (isoenzyme-X) was linked to the first wave of pachytene primary spermatocytes in rats.

Hyaluronidase is not detectable by 20 days of age, indicating that it is not associated with spermatogonia or early spermatocytes. Appearance of activity as early as 23 days of age and the rapid increase in activity thereafter suggests its association with late spermatocytes and early spermatids. Males \& Turkington (1970), however, reported that hyaluronidase activity first became detectable in rats with formation of the cap phase spermatids at 33-34 days of age.

The detection of sorbitol dehydrogenase activity in 1-day-old mice suggests that this enzyme might be present in the fetal testis. The close correlation of activity and testicular weight was similar to results obtained in rats by Mills \& Means (1972).

The demonstration of $\alpha$-glycerophosphate dehydrogenase activity in newborn mice also implies that this enzyme is associated with the differentiating spermatogonia. However, the increase in 
activity from 1 to 35 days of age, as other spermatogenic cells appear in the seminiferous tubules, seems to indicate that this enzyme is also associated with more advanced germinal cells.

By histochemical methods, it has been shown that malate dehydrogenase in rats (Ambadkar \& George, 1964), glucose-6-phosphate dehydrogenase in rats (Blackshaw \& Elkington, 1970), and isocitrate dehydrogenase in mice (Hitzeman, 1962) are more active in interstitial cells than in the seminiferous tubules. Baillie (1961) calculated that $>70 \%$ of the newborn mouse testis is interstitial tissue, and this decreases to 17,6 and $4 \%$ on 7,14 and 21 days of age, respectively. Hitzeman (1962) found that mitotic activity of the interstitial cells decreased in the neonatal mouse to stable levels by 15 days of age. Steinberger \& Steinberger (1971) reported that proliferation of Sertoli cells in rat tissue ceased after Day 15. It is therefore possible that the decrease in activities of malate, glucose-6phosphate and glyceraldehyde-3-phosphate dehydrogenases at 20 days of age may not only be due to the transformation of spermatocytes to spermatids but also to the relative decrease in the numbers of Sertoli and interstitial cells.

The results, suggesting that the first wave of mature spermatozoa is released into the epididymis at 37 days of age, agrees with data published by Gomes (1970) and Bruce \& Meistrich (1972). The low epididymal glucose-6-phosphate dehydrogenase activity in adult mice reflects low activity in spermatozoa, as indicated by the extremely low activity in the vas deferens.

\section{References}

Ambadkar, P.M. \& GeorGe, J.C. (1964) Histochemical localization of certain oxidative enzymes in the rat testis. J. Histochem. Cytochem. 12, 587-590.

BAILliE, A.H. (1961) Observation on the growth and histochemistry of the Leydig tissue in the postnatal prepubertal mouse testis. J. Anat. 95, 357-370.

BERGMEYER, H.U. (1974) Methods of Enzymatic Analysis, 2nd English edn. Verlag Chemie, Weinheim.

BlaCKSHAW, A.W. \& Elkington, J.S.H. (1970) Developmental changes in lactate dehydrogenase isoenzymes in the testis of the immature rat. $J$. Reprod. Fert. 22, 69-75.

Bruce, W.R. \& Meistrich, M.L. (1972) Spermatogenesis in the mouse. In Cell Differentiation, pp. 295-299. Eds R. Harris, P. Allin \& D. Viza. Munksgaard, Copenhagen.

Go, V.L.W., Vernon, R.G. \& Fritz, I.B. (1971) Studies on spermatogenesis in rats. I. Application of the sedimentation velocity technique to an investigation of spermatogenesis. Can. J. Biochem. 49, 753-760.

Goldrerg, E. \& Hawtrey, C. (1967) The ontogeny of sperm specific lactate dehydrogenase in mice. J. exp. Zool. 164, 309-316.

Gomes, W.R. (1970) Chemical agents affecting testicular function and male fertility. In The Testis, vol. III, pp. 483-554. Eds A. D. Johnson, W. R. Gomes \& N. L. VanDemark. Academic Press, New York.

Gomes, W.R. \& VANDemark, N.L. (1974) The male reproductive system. $A$. Rev. Physiol. 36, 307-330.

HitzemaN, J.W. (1962) Development of enzyme activity in the Leydig cells of the mouse testis. Anot. Rec. 143, 351-361.

Hodgen, G.D. \& Sherins, R.J. (1973) Enzymes as markers of testicular growth and development in the rat. Endocrinology 93, 985-989.

LAM, D.M.K., Furrer, R. \& BruCE, W.R. (1970) The separation, physical characterization, and differentiation kinetics of spermatogonial cells of the mouse. Proc. natn. Acad. Sci. U.S.A. 65, 192-199.

LEE, I.P. \& DIXON, R.L. (1972) Antineoplastic drug effects on spermatogenesis studied by velocity sedimentation cell separation. Toxic. appl. Pharmac. 23, $20-41$.

Lowry, O.H., Rosebrough, N.J., FArR, A.L. \& RANDAlL, R.J. (1951) Protein measurement with the Folin phenol reagent. J. biol. Chem. 193, 265-275.

Males, J.L. \& Turkington, R.W. (1970) Hormonal regulation of hyaluronidase during spermatogenesis in the rat. J. biol. Chem. 245, 6329-6334.

MEISTRICH, M.L. (1972) Separation of mouse spermatogenic cells by velocity sedimentation. J. Cell Physiol. 80, 299-312.

Mills, N.C. \& Means, A.R. (1972) Sorbitol dehydrogenase of rat testis: changes of activity during development, after hypophysectomy and following gonadotrophic hormone administration. Endocrino$\log y$ 91, 147-156.

Schanbacher, B.D., Gomes, W.R. \& VanDemark, N.L. (1974) Testicular carnitine acetyltransferase activity and serum testosterone levels in developing and cryptorchid rats. J. Reprod. Fert. 41, 435-440.

SCHENKMAN, J.B., RicherT, D.A. \& WESTERFELD, W.W. (1965) $\alpha$-Glycerophosphate dehydrogenase activity in rat spermatozoa. Endocrinology 76, 1055-1061.

Steinberger, A. \& Steinberger, E. (1971) Replication pattern of Sertoli cells in maturing rat testis in vivo and in organ culture. Biol. Reprod. 4, 84-87. 